\title{
The importance of traditional agricultural landscapes for preventing species extinctions
}

\author{
Ove Eriksson $^{1}$
}

Received: 17 August 2020 / Revised: 15 February 2021 / Accepted: 16 February 2021 /

Published online: 1 March 2021

(C) The Author(s) 2021

\begin{abstract}
The main paradigm for protection of biodiversity, focusing on maintaining or restoring conditions where humans leave no or little impact, risks overlooking anthropogenic landscapes harboring a rich native biodiversity. An example is northern European agricultural landscapes with traditionally managed semi-natural grasslands harboring an exceptional local richness of many taxa, such as plants, fungi and insects. During the last century these grasslands have declined by more than $95 \%$, i.e. in the same magnitude as other, internationally more recognized declines of natural habitats. In this study, data from the Swedish Red List was used to calculate tentative extinction rates for vascular plants, insects (Lepidoptera, Coleoptera, Hymenoptera) and fungi, given a scenario where such landscapes would vanish. Conservative estimates suggest that abandonment of traditional management in these landscapes would result in elevated extinction rates in all these taxa, between two and three orders of magnitude higher than global background extinction rates. It is suggested that the species richness in these landscapes reflects a species pool from Pleistocene herbivore-structured environments, which, after the extinction of the Pleistocene megafauna, was rescued by the introduction of pre-historic agriculture. Maintaining traditionally managed agricultural landscapes is of paramount importance to prevent species loss. There is no inherent conflict between preservation of anthropogenic landscapes and remaining 'wild' areas, but valuating also anthropogenic landscapes is essential for biodiversity conservation.
\end{abstract}

Keywords Anthropogenic landscapes · Extinction rates · Insects · Livestock grazing · Megafauna $\cdot$ Plants

Communicated by Jan C Habel.

Ove Eriksson

ove.eriksson@su.se

1 Department of Ecology, Environment and Plant Sciences, Stockholm University, 10691 Stockholm, Sweden 


\section{Introduction}

The current discourse on global biodiversity decline is strongly focused on anthropogenic impacts as a major threat and that actions need to be taken to reduce these impacts. There are good reasons for this generalization. Anthropogenic transformation of natural habitats is a main driver behind global species loss (Brummitt et al. 2015; IPBES 2019) and projected species extinction rates are estimated to be several orders of magnitude higher than background extinction rates (Pereira et al. 2010; Barnosky et al. 2011; Pimm et al. 2014; Ceballos et al. 2015; Humphreys et al. 2019). To counteract this loss of biodiversity, a dominating course of action is to preserve remaining 'wild' areas and to strive toward increasing these, e.g. by 'giving back land to nature' (e.g. Wilson 2016; Pimm et al. 2018), by prioritizing land sparing (e.g. Phalan et al. 2011, 2016), and by restoration of habitats to a state which is similar to that they would have had in the absence of human activities (e.g. Garibaldi et al. 2020). Accordingly, this paradigm for protection of biodiversity equals maintaining or restoring conditions where humans leave no or little impact. However, there is a risk that this paradigm overlooks traditionally managed anthropogenic landscapes harboring a rich native biodiversity. Such landscapes may comprise a variety of habitats and ecological conditions suitable for many species (e.g. Eriksson et al. 2002; Emanuelsson 2009; Tscharntke et al. 2012; Berglund et al. 2014; Plieninger et al. 2015; Tieskens et al. 2017; Angelstam et al. 2020). Although the importance of anthropogenic landscapes for current biodiversity has been acknowledged in many studies, a common feature of these studies is that they remark that this issue either has been neglected (e.g. Pimentel et al. 1992; Poschlod and WallisDeVries 2002; Plieninger et al. 2006; Bliege Bird and Nimmo 2018), or that current policy measures for maintaining these landscape's biodiversity are insufficient (e.g. Fischer et al. 2012; Raatikainen and Barron 2017). A starting-point for the present paper is that it would be valuable to have quantitative assessments of the effects on biodiversity of abandonment of traditionally managed anthropogenic landscapes, using approaches similar to the global assessments of species extinctions mentioned above.

The objective of this paper is to examine the potential loss of species, assessed as projected species extinction rates, if traditional agricultural landscapes would cease to exist, using Sweden as an example. The term 'traditional' here means landscapes maintaining features reflecting old-fashioned management, rooted in times before agriculture and forestry were modernized from the late nineteenth century onwards. In Sweden, as in many other parts of Europe, a long history of agricultural management, largely based on livestock as a key component, have formed such landscapes (Emanuelsson 2009), and there are still relatively large areas in Sweden maintaining features of traditional management, particularly remaining semi-natural grasslands (Eriksson and Cousins 2014). These grasslands are termed semi-natural because they are dominated by a native species pool, and only to a limited extent are influenced by fertilization, plowing or sowing. Due to modernization of agriculture and forestry during the last 100-150 years, semi-natural grasslands have declined drastically all over Europe (e.g. Veen et al. 2009; Eriksson and Cousins 2014; Plieninger et al. 2015). Fuller (1987) estimated that $97 \%$ of unimproved grassland (i.e. semi-natural grassland) in England and Wales was lost between 1932 and 1984. Ridding et al. (2015) estimated that $47 \%$ of semi-natural grasslands in England was lost between 1960 and 2013. Luoto et al. (2003) concluded that in Finland, only about $1 \%$ of the semi-natural grasslands of 1880 remains until the present day. For one province in Sweden, Cousins et al. (2015) estimated that semi-natural grassland cover has decreased by over $96 \%$ 
since the year 1900. In Sweden, traditionally managed hay-meadows, i.e. land that was specifically used for production of livestock fodder, more or less ceased to exist after modernization of agriculture from the late nineteenth century onwards, and currently approximately $1.7 \%$ of the area of semi-natural meadows are still managed for haymaking as compared to 1927 (Swedish Board of Agriculture 2019). Until the late nineteenth century, vast areas was used for forest grazing in Sweden. Compared with 1927, about 2\% of these grazed forests remains (Swedish Board of Agriculture 2019).

Approximately 270,000 hectares of species-rich semi-natural grasslands remain in Sweden, of which c. 98\% are currently maintained by livestock grazing (Swedish Board of Agriculture 2005). Due to a relatively recent abandonment of grazing management, and a typically quite slow plant population response to land-use change, there are also areas (unknown how large) that could potentially be restored (e.g. Waldén and Lindborg 2016).

This loss of semi-natural grasslands is in the same magnitude as other, internationally more well-known and recognized declines of natural habitats, for example the Atlantic rainforest in Brazil where (depending on region) 1-12\% of forest area remains today (Saatchi et al. 2001), and natural forests in Madagascar, which have been subjected to a loss of c. 44\% during the period 1953-2014 (Vieilledent et al. 2018). Similar to tropical forests (Laurance et al. 2018), fragmentation of remaining seminatural grasslands implies an additional problem due to loss of dispersal routes, and decreasing functional connectivity (Poschlod and Bonn 1998; Bruun and Fritzbøger 2002; Auffret et al. 2015). For example, Manton and Angelstam (2018) estimated that remaining grassland fragments more or less completely have lost the functionality for harboring several bird species.

In addition to the direct ecosystem services gained from biodiversity of grasslands (e.g. Bengtsson et al. 2019), and their values as essential components of historical cultural landscape history (Emanuelsson 2009; Eriksson 2016), semi-natural grasslands harbor an exceptional plant species diversity at small spatial scales (Wilson et al. 2012). One often finds more than 40 species of flowering plants in a single square meter. The reduction in area of semi-natural grasslands thus directly causes decline in many plant species. The diversity of flowering plants in semi-natural grasslands provides habitat for numerous insects (Dover et al. 2011; Milberg et al. 2016; RotchésRibalta et al. 2018). For example, semi-natural grasslands are the most important habitat for European butterflies (lepidopterans), many of which are currently threatened (van Swaay et al. 2006; Kuussaari et al. 2007). Several studies also report declines in the diversity of hymenopterans (i.e. bees, wasps, ants) during the last century, and decline or change in grassland management is considered as one of the most important causes (e.g. Bommarco et al. 2012; Ollerton et al. 2014). Overall, insects have been reported to decline worldwide (e.g. Sánchez-Bayo and Wyckhuys 2019), and the taxa mentioned above, lepidopterans and hymenopterans, are among those affected most. In addition to plants and insects, semi-natural grasslands are key habitats for many species of fungi (Rydin et al. 1997) and for many birds (e.g. Manton and Angelstam 2018). Overall, approximately a third of Red Listed species in Sweden are strongly dependent on traditional agricultural landscapes, where semi-natural grasslands are key habitats (Eide et al. 2020).

Based on this background, the specific question asked in this study is: What are the projected species extinction rates for vascular plants, insects (Lepidoptera, Coleoptera, Hymenoptera) and fungi, in a scenario where traditional agricultural landscapes in Sweden would cease to exist? 


\section{An approach to assess species extinction rates}

The extinction of a species is technically when the last individual of that species dies. It is difficult to detect when this happens, or if it has happened, and in the conservation literature there is a discussion on how one should infer extinctions using different data sources (e.g. Collen et al. 2010). Furthermore, in practice, one may consider a species functionally extinct long before the final disappearance of the last individual. This is well illustrated by one of the most charismatic of the extinct Pleistocene megafauna, the woolly mammoth. Lister (2014) described how the abundance and distribution of woolly mammoth changed over the course of the last 40,000 years. A decline is detected from around 21,500 years BP, and was particularly pronounced after a warming period commencing around 14,700 years BP. From 12,000 years BP, woolly mammoths only occurred in northern Siberia, ultimately leading to a distribution confined to some small islands outside the northern Siberian coast. The woolly mammoth finally went extinct in Wrangel Island around 4000 years BP. Thus, extinction can be seen as a drawn-out process, rather than as a time-specific event, as is implicit in the concept of extinction debt (e.g. Tilman et al. 1994; Hylander and Ehrlén 2013), meaning that species may be doomed, but have not yet disappeared completely.

The view that species extinction is an extended process rather than a time specific event lies behind an approach to estimate extinction rates based on IUCN assessments of extinction risks (Mace et al. 2008; IUCN 2019) advocated by Smith et al. (1993a, b). This approach is commonly employed (e.g. Mace 1994; Stork 2010; Barnosky et al. 2011; Pimm et al. 2014). Using taxa that are assumed to be comparatively well studied, information on the total number of species of that taxon, the number of species considered threatened, and an assumption of the threatened species' fate during a coming specified time-period, extinction rates can be estimated. The estimated extinction rates are then compared with a background extinction rate, i.e. the rate of extinction that is considered natural. Smith et al. (1993b) suggested that species fate could be assessed for example by examining trends in the IUCN status classification, but it has been noticed that such trends may in fact reflect changes in the state of knowledge rather than real changes in the species' status (e.g. Pimm et al. 2014; Eide et al. 2020). Extinction rates are expressed with the metric E/MSY (extinctions per million species-years) (Pimm et al. 1995). de Vos et al. (2014) and Pimm et al. (2014) argued that an accurate estimate of average background extinction rate would be approximately 0.1 E/MSY, i.e. lower than previously used estimates of 1-2 E/MSY (e.g. Barnosky et al. 2011; Ceballos et al. 2015).

\section{Methods}

In order to try answering the question 'How would disappearance of traditional agricultural landscapes affect species extinctions?' information was compiled from the Swedish Red List (SLU ArtDatabanken 2020). In this list, all species are assigned to one or several landscape types, and for each species there is an assessment of whether each landscape type is particularly important for that species. The approach used was to include only those species that are considered dependent on agricultural landscapes, i.e. for which agricultural landscapes are particularly important. In the Red List, 'agricultural landscape' mainly refers to landscapes with semi-natural grasslands (Eide et al. 2020), but includes also some other habitats, for example ditches, ponds and small fields. These features are all associated 
with remains of old-fashioned management, qualifying that agricultural landscapes in the Red List corresponds to remains of traditional agricultural landscapes. However, making autecological assessments to identify specific habitats for species within agricultural landscapes, although possible for some species, would have been very difficult since the regional population dynamics are very poorly studied for most species.

The three categories of threated species: CR (Critically Endangered), EN (Endangered), and VU (Vulnerable) were considered. Species categorized as RE (Regionally Extinct) and DD (Data Deficient) were excluded. Varieties and apomictic taxa were also excluded.

Data was compiled for vascular plants, lepidopterans (e.g. butterflies and moths), hymenopterans (e.g. bees, wasps and ants), coleopterans (beetles), and fungi (including Ascomycota and Basidiomycota), and for each of these five taxa, projected extinction rates were calculated.

In order to calculate extinction rates using the metric E/MSY, one first has to estimate $\mathrm{E}$, i.e. the number of species expected to go extinct given the scenario that traditionally managed agricultural landscapes would cease to exist. In the calculations, this number equaled the number of species, for each of the five taxa, categorized as threatened (CR, EN or VU). The value of the denominator, MSY, 'million species-years', was calculated using the number of species of each taxon that has been assessed in the Swedish Red List, multiplied by a chosen time period. The resulting figure was scaled to million species-years.

All calculations were based on a time-period of 100 years, i.e. if management of traditional agricultural landscapes with semi-natural grasslands would cease today, the threated species in these landscapes would be regionally extinct within 100 years. This time-period was chosen because many plant species have been found to respond slowly to land-use change, and remnant populations may remain approximately a century, i.e. somewhere between 50 and 200 years (e.g. Lindborg and Eriksson 2004; Herben et al. 2006). This is probably too a long time-period for species in other taxa, such as short-lived species as insects, so the choice of time-period is likely to be conservative.

In order to get a range of extinctions rates, two alternative methods were used for each of the five taxa. In the Swedish Red List, a threatened species may be assigned to one or several landscape types. In the calculations of extinction rates, the least conservative method was based on all species for which agricultural landscapes are important, irrespective of whether the species also inhabit other landscapes, e.g. wetlands, forests or urban habitats. Thus, including all these species may overestimate extinction rates. Therefore, a second calculation was made, including only those species restricted to agricultural landscapes. The two calculated extinction rates thus cover a range from less, to more conservative estimates.

\section{Results}

The results are presented in Fig. 1 and Table 1. For vascular plants almost all species in Sweden have been assessed in the preparation of the Swedish Red List. Of a total of 1599 assessed species, 434 are on the Red List (this includes also the categories NT, near threatened, DD, data deficient, and RE, regionally extinct). Of these, 157 species (36.2\%) are threatened (i.e. categorized as CR, critically endangered, EN, endangered, or VU, vulnerable) and at least partly dependent on traditional agricultural landscapes. Assuming that these species would disappear if these landscapes vanished, that would imply that c. $10 \%$ of vascular plant species in Sweden went extinct. Using a time-period 
Extinction rate (E/MSY)

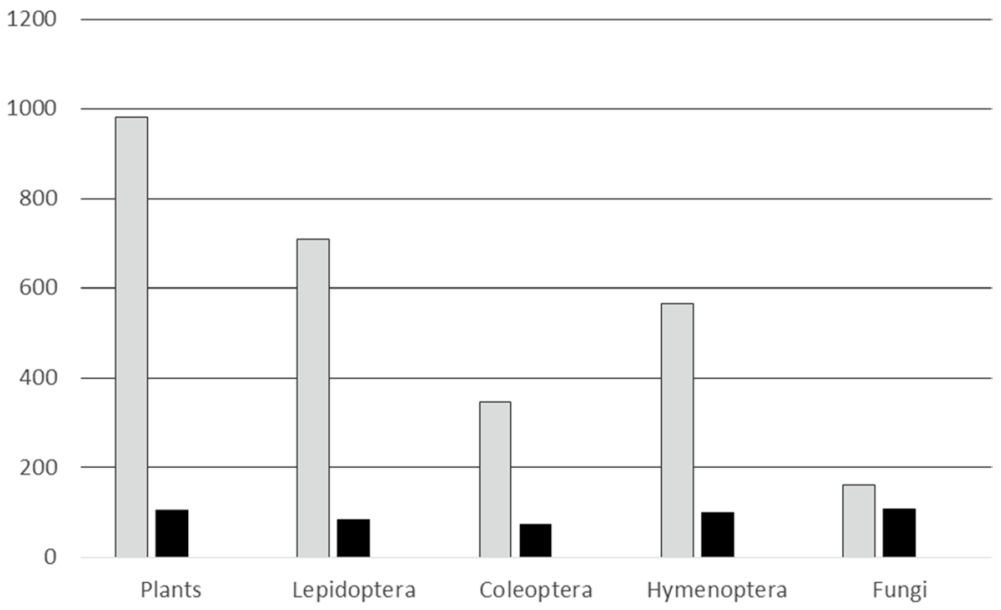

Fig. 1 Projected extinction rates for five taxa under a scenario when management of traditional agricultural landscapes would vanish. The grey bars are based on all threatened species for which agricultural landscapes are important. Black bars are based only on species restricted to agricultural landscapes

Table 1 Estimated extinction rates for five taxa based on the 2020 Swedish Red List

\begin{tabular}{llllll}
\hline Taxon & Plants & Lepidoptera & Coleoptera & Hymenoptera & Fungi \\
\hline \# Assessed species & 1599 & 2626 & 4373 & 1008 & 3628 \\
Fraction of total \# species & $99 \%$ & $100 \%$ & $98 \%$ & $12 \%$ & $65 \%$ \\
\# Red listed species & 434 & 549 & 933 & 250 & 851 \\
\# Species: AL important & 157 & 186 & 151 & 57 & 58 \\
\# Species: AL only & 17 & 22 & 32 & 565 & 39 \\
Extinction rate 1 (E/MSY) & 982 & 708 & 73 & 99 & 160 \\
Extinction rate 2 (E/MSY) & 106 & 84 & & 107 \\
\hline
\end{tabular}

'Plants' refer to vascular plants. 'Fungi' refers to Ascomycota and Basidiomycota. '\# Species: AL important' are threatened species for which agricultural landscapes are important, but also including species inhabiting other landscapes. '\# Species: AL only' are threatened species which are restricted to agricultural landscapes. Extinction rate 1 is based on '\# Species: AL important'. Extinction rate 2 is based on '\# Species: AL only'. E/MSY is number of extinctions per million species-years

$A L$ agricultural landscapes

of 100 years for this extinction process yielded an estimated extinction rate of $982 \mathrm{E} /$ MSY. If the calculation was instead based only on those 17 species exclusively inhabiting agricultural landscapes, the estimated extinction rate was $106 \mathrm{E} / \mathrm{MSY}$.

Also for lepidopterans and coleopterans, most species have been assessed. If all 186 threatened lepidopteran species at least partly dependent on traditional agricultural landscapes would disappear if these landscapes vanished, that would imply that c. $7 \%$ of all species in Sweden went extinct. For lepidopterans, the estimated extinction rates based on the two ways of selecting species were 708 and 84 E/MSY, respectively.

For coleopterans, the corresponding estimated extinction rates were 345 and $73 \mathrm{E} /$ MSY. A relatively small fraction of all Red Listed coleopterans live in agricultural 
landscapes (16.2\%) compared to vascular plants (36.2\%) and lepidopterans (33.9\%); many coleopterans depend on wood and mostly occur in forests. However, the fraction of the species living in agricultural landscapes which is restricted to these landscapes was higher among coleopterans $(21.2 \%)$ than for vascular plants (10.8\%) and lepidopterans $(11.8 \%)$.

For two of the taxa, a large fraction of species has not been assessed in the Red List. This is most pronounced for hymenopterans, where only $12 \%$ of the species have been assessed. This means that the estimated extinction rate is based on an additional assumption: that the assessed species are an unbiased sample of all species. This is probably not a valid assumption, and therefore the extinction rates for hymenopterans must be taken with more caution than for the preceding three taxa. The calculated extinction rates were 565 and $99 \mathrm{E} / \mathrm{MSY}$, respectively.

For fungi, $65 \%$ of the species have been assessed. Using the same assumption as for hymenopterans, that the assessed species are an unbiased sample of all species, this yielded estimated extinction rates of 160 and 107 E/MSY. Only 6.8\% of the species of Red Listed fungi inhabit agricultural landscapes, most species occur in forests. For those threatened species of fungi that do inhabit agricultural landscapes, however, a large fraction of species are restricted to these landscapes (67.2\%). This is reflected in the comparatively small difference between the two estimates of extinction rate.

\section{Discussion}

On maps representing biodiversity hotspots, global biodiversity patterns and threats to biodiversity, northern Europe is typically blank (e.g. Myers et al. 2000; Pimm et al. 2014; Tilman et al. 2017). This representation is also found in commonly used undergraduate textbooks (e.g. Gaston and Spicer 2004) communicating the impression that nothing of major interest for biodiversity takes place in this part of the world. As the results show, this view overlooks that traditional agricultural management has shaped anthropogenic landscapes with exceptionally rich biodiversity, and that large parts of this biodiversity run the risk of becoming extinct in the near future.

From the standpoint of a conservation paradigm focused on 'wild' nature as a prerequisite for high biodiversity, it may seem paradoxical that any anthropogenic landscape is so species-rich, and that many species seem to be confined to these anthropogenic landscapes. Agriculture reached northern continental Europe during the 6th millennium BC, equipped with a complete farming package, including cattle (e.g. Rowley-Conwy 2011; McClure 2015). Since species exist for a much longer time, there has to be some 'natural' (here used in the meaning 'not influenced by humans') environment where these species lived before the arrival of agriculture.

Most discussions on this issue revolve around a suggestion by Vera (2000) that preagricultural landscapes during the Holocene were shaped by large herbivores creating a grassland-forest mosaic, resembling the landscape that later was formed by agriculture; the 'wood pasture hypothesis'. However, this hypothesis has been questioned (e.g. Mitchell 2005; Whitehouse and Smith 2010), and vegetation reconstructions based on pollen (e.g. Roberts et al. 2018) suggest that forests dominated Europe during mid Holocene, with a maximum cover between 6000 and 4000 BC, despite that open habitats occurred locally (Svenning 2002; Auffret and Cousins 2018; Feurdean et al. 2018). 
Although Vera's wood-pasture hypothesis in its original version thus can be questioned based on evidence, it may hold if the timeframe is extended to the whole Pleistocene (e.g. Andersson and Appelqvist 1990; Gill 2013). Before the last glaciation there was a diverse and abundant fauna of large herbivores in the northern hemisphere: elephants, rhinos, cervids, bovids and horses (e.g. Bradshaw et al. 2003; Rivals and Lister 2016; Lister 2014). Recent studies suggest that steppe communities at this time were dominated by forbs (Willerslev et al. 2014), and mycorrhizal associations were dominated by AM fungi, typical for grasslands (Zobel et al. 2018). Fossil remains of dung beetles were more abundant before the last glaciation than in the early Holocene (Sandom et al. 2014). Put together, this evidence suggests that vegetation during the Pleistocene was strongly influenced by large herbivores.

A large fraction of the Pleistocene megafauna went extinct between 50,000 and 10,000 years BP (e.g. Koch and Barnosky 2006; Meltzer 2015), and as an effect of the extinction of large herbivores, forest cover and density increased (Johnson 2009; Gill 2013), creating the forest dominated vegetation during mid Holocene. The advent of agriculture in Europe changed this landscape and other mechanisms promoting species richness were introduced in the anthropogenic landscapes (Eriksson 2013). Large areas of open or semi-open grasslands appeared and human settlement structure became increasingly permanent, grassland connectivity increased, and movement of people and livestock promoted dispersal of seeds. Species-richness in semi-natural grasslands is generally promoted by low levels of nutrients, and removal of biomass by grazing and mowing add to this effect by reducing the effects of potential competitive dominants. Grazing livestock also promote heterogeneity, due to dietary choices, creation of small-scale disturbances and deposition of dung and urine (e.g. Rook et al. 2004), and they promote seed dispersal within pastures (e.g. Kiviniemi and Eriksson 1999). Grassland heterogeneity has been found positive for diversity of plants (e.g. Öster et al. 2007), as well as for insects (e.g. Sjödin et al. 2008; van Klink et al. 2015; Bonari et al. 2017).

Accordingly, the species pool that once inhabited the herbivore-structured landscapes of the Pleistocene may, along with the post-glacial migration, have been rescued by the advent of agriculture, and the creation of open habitats used for grazing and mowing. As succinctly stated by Johnson (2009, p. 2516): "To understand living plant communities, we need to re-imagine them with their full complement of Pleistocene megafauna". As a corollary, the current abandonment of managing these landscapes, as summarized in the introduction, leads to elevated extinctions in this species pool.

The results suggest that even the most conservative estimate, focusing on species restricted to agricultural landscapes, yield projected extinction rates for all five taxa that are around two to three orders of magnitude higher than the background extinction rate, using the figure (0.1 E/MSY) suggested by de Vos et al. (2014) and Pimm et al. (2014). A global background extinction rate is likely to be lower than a hypothetical 'regional background extinction rate' because species with a wide geographic range probably disappear regionally at a faster rate (e.g. Pimm et al. 2014). One should thus acknowledge that a background extinction rate of $0.1 \mathrm{E} / \mathrm{MSY}$ may be too low as a reference point in the context of this study, since it was based on data for just one country. Unfortunately, we have no knowledge on regional background extinction rates, but this problem motivates some caution when interpreting the results. However, one reason for considering this problem as not too serious is that many of the species threatened in Sweden are in fact facing the same situation of disappearing semi-natural grasslands all over Europe (as mentioned in the Introduction). A comparison with global background extinction rates would thus seem appropriate. In addition, while the time period used for extinction 


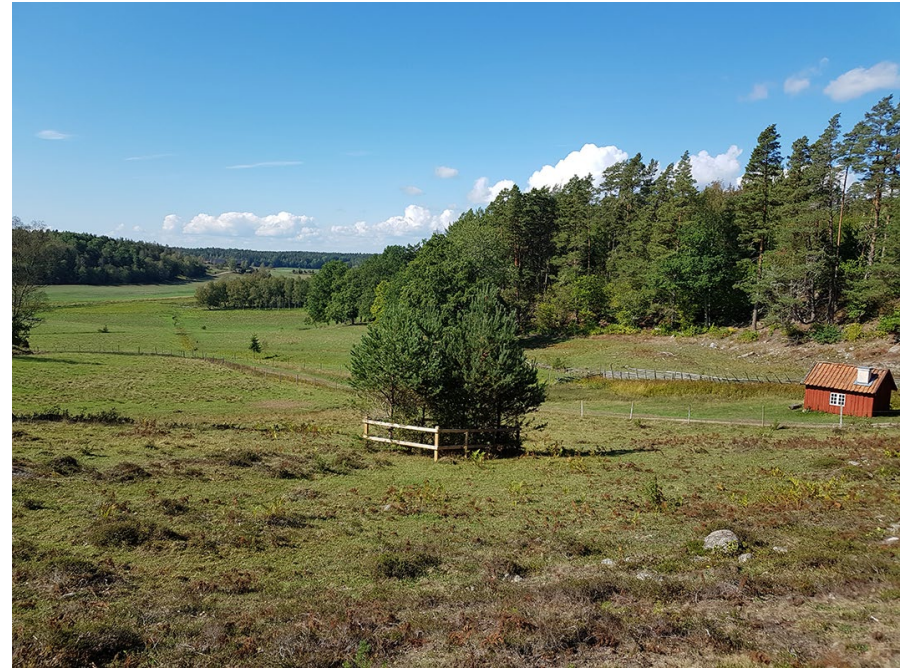

Fig. 2 The future of semi-natural grasslands? As part of an experiment on litter decomposition initiated in 2004, small grazing exclosures were established in a semi-natural grassland at Långmaren, c. $100 \mathrm{~km}$ south of Stockholm, Sweden. After the experiment was completed, the land manager decided to maintain some of the exclosures to show visitors what would happen if grazing would cease. The photo was taken in 2018 , thus showing the encroachment after 14 years of abandonment of grazing. This site harbors an exceptional local-scale plant species richness, a rich fauna of butterflies, and several Red Listed insects, for example the endangered drum grasshopper (Psophus stridulus). Without grazing, the whole area would soon turn into a species-poor, dense forest. The photo illustrates that a time-period of 100 years may be too conservative for estimating extinction rates in semi-natural grasslands. Photo: The author

after abandonment of traditional management, 100 years, is reasonable for vascular plants, it is likely to be too long for short lived organisms such as insects (Fig. 2). If, for example, 10 years was chosen instead, that would increase the extinction rate by one order of magnitude.

Based on these projected increases of extinction rates one may ask whether species loss has already started. Using the same criterion (species for which agricultural landscapes are important), the number of species recorded as RE ('Regionally Extinct') in the Swedish Red List (SLU ArtDatabanken 2020) is 15 (vascular plants), 16 (lepidopterans), 21 (coleopterans), 12 (hymenopterans) and 1 (fungi). These figures may seem small, given the decline of semi-natural grasslands over the last 100-150 years. One possible explanation is that the elevated extinction rates have not yet become manifested in realized extinctions because the remains of traditional agricultural landscapes have been sufficient to prevent extinctions. Furthermore, due to a slow response to land-use change by many plants, there are large areas (unknown how large) that still maintain features of previously managed grasslands. Extinction may be a slow process, particularly for plants (e.g. Cronk 2016).

A related question is whether disappearance of semi-natural grasslands by abandonment of grazing or mowing management (Fig. 2) automatically mean disappearance of all the inhabitant species. Also the traditional agricultural landscape was once a 'novel ecosystem' (cf. Hobbs et al. 2009) and there may be new habitats in the modern landscapes where these species thrive, at least to some extent. Many species occur in regional metapopulations (e.g. Hanski et al. 2017), and maintenance of such 
metapopulations is dependent on the structure and composition of whole landscapes, for example habitat connectivity (e.g. Pérez-Sánchez et al. 2020) and relationship between forest and open land (e.g. Bergman et al. 2018). Also habitats other than semi-natural grasslands may contribute to such landscape level features. Some plant species typical for semi-natural meadows inhabit road verges if these are properly managed (Auestad et al. 2011), and the same holds for some insects (Kuussaari et al. 2007). Power line corridors may harbor both insects (Berg et al. 2016) and plants (Svensson et al. 2017) which are considered typical for semi-natural grasslands. Gardens and urban parks may serve similar functions. Ex-arable fields transformed for grazing will to some extent be colonized by semi-natural grassland plants (Cousins and Aggemyr 2008; Öster et al. 2009). This of course depends on continuing grazing management on these lands. Whether these new anthropogenic habitats are sufficient for species long-term survival, or if they are just what Wrangel Island was for woolly mammoths (Lister 2014), a transient last resort, is an open question.

Even if these possible caveats and the inherent lack of precision in estimates of species extinction rates based on Red List data are taken into consideration, it is clear that the investigated anthropogenic landscapes, traditional Scandinavian agricultural landscapes preserving remains of historical management, host a considerable threatened biodiversity. A large part of this biodiversity risks extinction if these landscapes cease to be managed, and the magnitude of the rates of species extinction is similar to what has been estimated for global species loss (e.g. Humphreys et al. 2019). It is reasonable that this conclusion holds not only for the traditional anthropogenic landscapes in northern Europe investigated here, but also for other anthropogenic landscapes where there has been a long history of management, for example in the Mediterranean (e.g. Marull et al. 2015) and in Asia (e.g. Berglund et al. 2014). A 'wild' nature paradigm as a role model for conservation (e.g. Wuerthner et al. 2014; Wilson 2016; Pimm et al. 2018) is therefore insufficient for maintaining biodiversity. Considering that most of Earth's landscapes are more or less anthropogenic (Ellis and Ramankutty 2008), one may also question the realism of removing human impacts from a large fraction of Earth's terrestrial surface (e.g. Mehrabi et al. 2018).

Even though it is in a sense well-known that cultural landscapes with a long history of human impacts harbors a high biodiversity (see Introduction), this aspect is often neglected. As stated by Bliege Bird and Nimmo (2018, p. 1052): “(...) it is surprising that the rewilding movement, and the ecological sciences in general, have so far largely failed to recognize the long evolutionary history of people in ecosystems." This neglect is illustrated by some recent suggestions aimed at climate change mitigation. In a publication from the European Academies Science Advisory Council (EASAC 2017), discussing the future of European forestry and its role in mitigating climate change as well as preservation of biodiversity and forest production itself, forests are seen as either 'wild' (or should be transformed to 'wild' forests), or as pure production forest. There is no mentioning of the role of previous history of forest grazing, despite the fact that this was perhaps the dominating use of European forests historically (e.g. Agnoletti and Santoro 2015), and that numerous species thrived in such anthropogenically impacted semi-open forests (e.g. Eriksson 2018). Another example is from a recent publication on sustainable food production (Willett et al. 2019). Although it is beyond doubt that meat production and consumption should decease globally, applying this global generalization to regional conditions may be detrimental to biodiversity. In fact, maintaining sustainable grazing in Swedish semi-natural grasslands may even necessitate an increase in land used for this purpose (e.g. Holmström et al. 2018), thus in turn necessitating an increasing market for meat produced on this land, in order to be economically sustainable for the farmers. 
It is important to stress that there is no inherent conflict between preservation of biodiverse anthropogenic landscapes and remaining areas that only to a minor extent have been subjected to human impact (e.g. Marris 2011, 2014; Mace 2014). Land-sparing and landsharing are not mutually exclusive (e.g. Fischer et al. 2014; Kremen 2015), and conservation programs can be successfully integrated in anthropogenic landscapes (e.g. Campagnaro et al. 2019). Furthermore, considering the extensive reduction in faunas worldwide (e.g. Dirzo et al. 2014) it has been proposed that rewilding should be applied to recreate natural trophic relationships involving large wild herbivores (e.g. Svenning et al. 2016). Maintaining livestock grazing in semi-natural grasslands would be an obvious complement to such rewilding programs (e.g. Garrido et al. 2019).

Recently, aspects of promoting relationships between people and biodiversity have been highlighted by the concepts relational values (Chan et al. 2016) and nature's contribution to people (Díaz et al. 2018). Learning and understanding the historic background of landscapes where anthropogenic impacts have promoted species richness is likely to stimulate both respect and interest in maintaining species, and may also provide insights useful for integrating conservation goals in working or domesticated landscapes (Ellis 2013, 2015; Crumley et al. 2018; Kremen and Merenlender 2018). Engaging stakeholders and the wider public is essential to combat the increasing loss of biodiversity (e.g. Campagnaro et al. 2019). After all, success in motivating goals for species conservation is more likely in landscapes where people actually live, and where they can experience the richness of biodiversity.

Acknowledgements I am grateful to S.A.O. Cousins, J. Ehrlén, A.M. Humphreys, K. Hylander and four anonymous reviewers for comments on the manuscript.

Funding Open access funding provided by Stockholm University.. No funding was received for conducting this study.

Data availability All data generated during this study is included in this published article. All data analysed is available in the reference SLU ArtDatabanken (2020) Rödlistade arter i Sverige 2020. SLU, Uppsala. (The 2020 Swedish Red List; In Swedish with English summary), listed in the reference list.

\section{Compliance with ethical standards}

Conflict of interest The author has no competing interests to declare.

Research involving human and animal rights The research does not involve humans or animals.

Open Access This article is licensed under a Creative Commons Attribution 4.0 International License, which permits use, sharing, adaptation, distribution and reproduction in any medium or format, as long as you give appropriate credit to the original author(s) and the source, provide a link to the Creative Commons licence, and indicate if changes were made. The images or other third party material in this article are included in the article's Creative Commons licence, unless indicated otherwise in a credit line to the material. If material is not included in the article's Creative Commons licence and your intended use is not permitted by statutory regulation or exceeds the permitted use, you will need to obtain permission directly from the copyright holder. To view a copy of this licence, visit http://creativecommons.org/licenses/by/4.0/. 


\section{References}

Agnoletti M, Santoro A (2015) Cultural values and sustainable forest management: the case of Europe. J Forest Res 20:438-444. https://doi.org/10.1007/s10310-015-0500-7

Andersson L, Appelqvist T (1990) The influence of the Pleistocene megafauna on the nemoral and the boreonemoral ecosystems. Sven Bot Tidskr 84:355-368 (in Swedish with English summary)

Angelstam P, Manton M, Yamelynets T, Fedoriak M, Albulescu A-C, Bravo F, Cruz F, Jaroszewicz B, Kavtarishvili M, Muños-Rojas J, Sijtsma F, Washbourna C-L, Agnoletti M, Dobrynin D, Izakovicova Z, Jansson N, Kanak R, Kopperoinen L, Lazdinis M, Metzger M, van det Moolen B, Özut D, Pavlovska Gjorgieska D, Stryamets N, Tolunay A, Zagidullina A (2020) Maintaining natural and traditional cultural green infrastructures across Europe: learning from historic and current landscape transformations. Landsc Ecol 36:637-663. https://doi.org/10.1007/s10980-020-01161-y

Auestad I, Rydgren K, Austad I (2011) Road verges: potential refuges for declining grassland species despite remnant vegetation dynamics. Ann Bot Fenn 48:289-303. https://doi.org/10.5735/085.048.0401

Auffret AG, Cousins SAO (2018) Land uplift creates important meadow habitat and a potential original niche for grassland species. Proc R Soc B 285:20172349. https://doi.org/10.1098/rspb.2017.2349

Auffret AG, Plue J, Cousins SAO (2015) The spatial and temporal components of functional connectivity in fragmented landscapes. Ambio 44:S51-S59. https://doi.org/10.1007/s13280-014-0588-6

Barnosky AD, Matzke N, Tomiya S, Wogan GOU, Swartz B, Quental TB, Marshall C, McGuire JL, Lindsey EL, Maguire KC, Mersey B, Ferrer EA (2011) Has the Earth's sixth mass extinction already arrived? Nature 471:51-57. https://doi.org/10.1038/nature09678

Bengtsson J, Bullock JM, Egoh B, Everson C, O’Connor T, O’Farrell PJ, Smith HG, Lindborg R (2019) Grasslands-more important for ecosystem services than you might think. Ecosphere 10:e02582. https://doi.org/10.1002/ecs2.2582

Berg Å, Bergman K-O, Wissman J, Żmihorski M, Öckinger E (2016) Power-line corridors as source habitat for butterflies in forest landscapes. Biol Conserv 201:320-326. https://doi.org/10.1016/j.bioco n.2016.07.034

Berglund BE, Kitagawa J, Lagerås P, Nakamura K, Sasaki N, Yasuda Y (2014) Traditional farming landscapes for sustainable living in Scandinavia and Japan: global revival through the Satoyama initiative. Ambio 43:559-578. https://doi.org/10.1007/s13280-014-0499-6

Bergman K-O, Dániel-Ferreira J, Milberg P, Öckinger E, Westerberg L (2018) Butterflies in Swedish grasslands benefit from forest and respond to landscape composition at different spatial scales. Landsc Ecol 33:2189-2204. https://doi.org/10.1007/s10980-018-0732-y

Bliege Bird R, Nimmo D (2018) Restore the lost ecological functions of people. Nat Ecol Evol 2:10501052. https://doi.org/10.1038/s41559-018-0576-5

Bommarco R, Lundin O, Smith HG, Rundlöf M (2012) Drastic historic shifts in bumble-bee community composition in Sweden. Proc R Soc B 279:309-315. https://doi.org/10.1098/rspb.2011.0647

Bonari G, Fajmon K, Malenovský I, Zelený D, Holuša J, Jongepierová I, Kočárek P, Konvička O, Uřičár̆ J, Chytrý M (2017) Management of semi-natural grasslands benefitting both plant and insect diversity: the importance of heterogeneity and tradition. Agric Ecosyst Environ 246:243-252. https://doi. org/10.1016/j.agee.2017.06.010

Bradshaw RHW, Hannon GE, Lister AM (2003) A long-term perspective on ungulate-vegetation interactions. Forest Ecol Manage 181:267-280. https://doi.org/10.1016/S0378-1127(03)00138-5

Brummitt NA, Bachman SP, Griffiths-Lee J et al (2015) Green plants in the Red: a baseline global assessment for the IUCN sampled Red List Index for plants. PLoS ONE 10:e0135152. https://doi. org/10.1371/journal.pone.0135152

Bruun HH, Fritzbøger B (2002) The past impact of livestock husbandry on dispersal of plant seeds in the landscape of Denmark. Ambio 31:425-431. https://doi.org/10.1579/0044-7447-31.5.425

Campagnaro T, Sitzia T, Bridgewater P, Evans D, Ellis EC (2019) Half earth or whole earth: what can Natura 2000 teach us? Bioscience 69:117-124. https://doi.org/10.1093/biosci/biy153

Ceballos G, Ehrlich PR, Barnosky AD, García A, Pringle RM, Palmer TM (2015) Accelerated modern human-induced species losses: entering the sixth mass extinction. Sci Adv 1:e1400253. https://doi. org/10.1126/sciadv.1400253

Chan KMA, Balvanera P, Benessaiah K, Chapman M, Díaz S, Gómez-Baggethun E, Gould R, Hannahs N, Jax K, Klain S, Luck GW, Martín-López B, Muraca B, Norton B, Ott K, Pascual U, Satterfield B, Tadaki M, Taggart J, Turner N (2016) Why protect nature? Rethinking values and the environment. Proc Natl Acad Sci USA 113:1462-1465. https://doi.org/10.1073/pnas.1525002113

Collen B, Purvis A, Mace GM (2010) When is a species really extinct? Testing extinction inference from a sighting record to inform conservation assessment. Divers Distrib 16:755-764. https://doi.org/10.111 1/j.1472-4642.2010.00689.x 
Cousins SAO, Aggemyr E (2008) The influence of field shape, area and surrounding landscape on plant species richness in grazed ex-fields. Biol Conserv 141:126-135. https://doi.org/10.1016/j.bioco n.2007.09.004

Cousins SAO, Auffret AG, Lindgren J, Tränk L (2015) Regional-scale land-cover change during the 20th century and its consequences for biodiversity. Ambio 44:S17-S27. https://doi.org/10.1007/s1328 0-014-0585-9

Cronk Q (2016) Plant extinctions take time. Science 353:446-447. https://doi.org/10.1126/science.aag1794

Crumley CL, Lennartsson T, Westin A (eds) (2018) Issues and concepts in historical ecology: the past and future of landscapes and regions. Cambridge University Press, Cambridge

de Vos JM, Joppa LN, Gittleman JL, Stephens PR, Pimm SL (2014) Estimating the normal background rate of species extinction. Conserv Biol 29:452-462. https://doi.org/10.1111/cobi.12380

Díaz S, Pascual U, Stenseke M et al (2018) Assessing nature's contribution to people: recognizing culture, and diverse sources of knowledge, can improve assessments. Science 359:270-272. https://doi. org/10.1126/science.aap8826

Dirzo R, Young HS, Galetti M, Ceballos G, Isaac NJB, Collen B (2014) Defaunation in the anthropocene. Science 345:401-406. https://doi.org/10.1126/science.1251817

Dover JW, Spencer S, Collins S, Hadjigeorgiou I, Rescia A (2011) Grassland butterflies and low intensity framing in Europe. J Insect Conserv 15:129-137. https://doi.org/10.1007/s10841-010-9332-0

EASAC (2017) Multi-functionality and sustainability in the European Union's forests. EASAC Policy Report 32. https://www.easac.eu. Accessed 14 Mar 2019

Eide W, Ahrné K, Bjelke U, Nordström S, Ottosson E, Sandström J, Sundberg S (2020) Tillstånd och trender för arter och deras livsmiljöer-rödlistade arter i Sverige 2020. SLU ArtDatabanken rapporterar 24. SLU ArtDatabanken, Uppsala (In Swedish with English summary)

Ellis EC (2013) Sustaining biodiversity and people in the world's anthropogenic biomes. Curr Opin Sustain 5:368-372. https://doi.org/10.1016/j.cosust.2013.07.002

Ellis EC (2015) Ecology in an anthropogenic biosphere. Ecol Monogr 85:287-331. https://doi. org/10.1890/14-2274.1

Ellis EC, Ramankutty N (2008) Putting people in the map: anthropogenic biomes of the world. Front Ecol Environ 6:439-447. https://doi.org/10.1890/070062

Emanuelsson U (2009) The rural landscape of Europe-How man has shaped European nature. The Swedish Research Council Formas, Stockholm

Eriksson O (2013) Species pools in cultural landscapes: niche construction, ecological opportunity and niche shifts. Ecography 36:403-413. https://doi.org/10.1111/j.1600-0587.2012.07913.x

Eriksson O (2016) Historical and current niche construction in an anthropogenic biome: old cultural landscapes in southern Scandinavia. Land 5:42. https://doi.org/10.3390/land5040042

Eriksson O (2018) What is biological cultural heritage and why should we care about it? An example from Swedish rural landscapes and forests. Nat Conserv Bulgaria 28:1-32. https://doi. org/10.3897/natureconservation.28.25067

Eriksson O, Cousins SAO (2014) Historical landscape perspectives on grasslands in Sweden and the Baltic region. Land 3:300-321. https://doi.org/10.3390/land3010300

Eriksson O, Cousins SAO, Bruun H-H (2002) Land-use history and fragmentation of traditionally managed grasslands in Scandinavia. J Veg Sci 13:743-748. https://doi.org/10.1658/11009233(2002)013[0743:LHAFOT]2.0.CO;2

Feurdean A, Ruprecht E, Molnár Z, Hutchinson SM, Hickler T (2018) Biodiversity-rich European grasslands: ancient, forgotten ecosystems. Biol Conserv 228:224-232. https://doi.org/10.1016/j.bioco n.2018.09.022

Fischer J, Hartel T, Kuemmerle T (2012) Conservation policy in traditional farming landscapes. Conserv Lett 5:167-175. https://doi.org/10.1111/j.1755-263X.2012.00227.x

Fischer J, Abson DJ, Butsic V, Chappell MJ, Ekroos J, Hanspach J, Kuemmerle T, Smith HG, von Wehrden H (2014) Land sparing versus land sharing: moving forward. Conserv Lett 7:149-157. https://doi.org/10.1111/conl.12084

Fuller RM (1987) The changing extent and conservation interest of lowland grasslands in England and Wales: a review of grassland surveys 1930-1984. Biol Conserv 40:281-300. https://doi. org/10.1016/0006-3207(87)90121-2

Garibaldi LA, Oddi FJ, Miguez FE, Bartomeus I, Orr MC, Jobbágy EG, Kremen C, Schulte LA, Hughes AC, Bagnato C, Abramson G, Bridgewater P, Gomez Carella D, Díaz S, Dicks LV, Ellis EC, Goldenberg M, Huaylla CA, Kuperman M, Locke H, Mehrabi Z, Santibañez F, Zhu C-D (2020) Working landscapes need at least 20\% native habitat. Conserv Lett. https://doi.org/10.1111/conl.12773 
Garrido P, Mårell A, Öckinger E, Skarin A, Jansson A, Thulin C-G (2019) Experimental rewilding enhances grassland functional composition and pollinator habitat use. J Appl Ecol 56:946-955. https://doi.org/10.1111/1365-2664.13338

Gaston KJ, Spicer JI (2004) Biodiversity: an introduction, 2nd edn. Blackwell, Oxford

Gill JL (2013) Ecological impacts of the late Quaternary megaherbivore extinctions. New Phytol 201:1163-1169. https://doi.org/10.1111/nph.12576

Hanski I, Schulz T, Wong SC, Ahola V, Ruokainen A, Ojanen SP (2017) Ecological and genetic basis of metapopulation persistence of the Glanville fritillary butterfly in fragmented landscapes. Nat Commun 8:14504. https://doi.org/10.1038/ncomms14504

Herben T, Münzbergová Z, Mildén M, Ehrlén J, Cousins SAO, Eriksson O (2006) Long-term spatial dynamics of Succisa pratensis in a changing rural landscape: linking dynamical modelling with historical maps. J Ecol 94:131-143. https://doi.org/10.1111/j.1365-2745.2005.01063.x

Hobbs RJ, Higgs E, Harris JA (2009) Novel ecosystems: implications for conservation and restoration. Trends Ecol Evol 24:599-605. https://doi.org/10.1016/j.tree.2009.05.012

Holmström K, Hessle A, Andersson H, Kumm K-I (2018) Merging small scattered pastures into large pasture-forest mosaics can improve profitability in Swedish suckler-based beef production. Land 7:58. https://doi.org/10.3390/land7020058

Humphreys AM, Govaerts R, Ficinski SZ, Lughadha EN, Vorontsova MS (2019) Global dataset shows geography and life form predict modern plant extinction and rediscovery. Nat Ecol Evol 3:10431047. https://doi.org/10.1038/s41559-019-0906-2

Hylander K, Ehrlén J (2013) The mechanisms causing extinction debts. Trends Ecol Evol 28:341-346. https://doi.org/10.1016/j.tree.2013.01.010

IUCN (2019) IUCN red list. https://www.iucnredlist.org/. Accessed 5 Apr 2019

IPBES (2019) Global assessment report on biodiversity and ecosystem services of the Intergovernmental Science-Policy Platform on Biodiversity and Ecosystem Services. Brondizio ES, Settele J, Díaz S, Ngo HT (eds). IPBES, Bonn

Johnson CN (2009) Ecological consequences of Late quaternary extinctions of megafauna. Proc R Soc B 276:2509-2519. https://doi.org/10.1098/rspb.2008.1921

Kiviniemi K, Eriksson O (1999) Dispersal, recruitment and site occupancy of grassland plants in fragmented habitats. Oikos 86:241-253. https://doi.org/10.2307/3546442

Koch PL, Barnosky AD (2006) Late quaternary extinctions: state of the debate. Annu Rev Ecol Evol Syst 37:215-250. https://doi.org/10.1146/annurev.ecolsys.34.011802.132415

Kremen C (2015) Reframing the land-sparing/land-sharing debate for biodiversity conservation. Ann N Y Acad Sci 1355:52-76. https://doi.org/10.1111/nyas.12845

Kremen C, Merenlender AM (2018) Landscapes that work for biodiversity and people. Science 362:eaau6020. https://doi.org/10.1126/science.aau6020

Kuussaari M, Heliölä J, Pöyry J, Saarinen K (2007) Contrasting trends of butterfly species preferring semi-natural grasslands, field margins and forest edges in northern Finland. J Insect Conserv 11:351-366. https://doi.org/10.1007/s10841-006-9052-7

Laurance WF, Camargo JLC, Fearnside PM, Lovejoy TE, Williamsson GB, Mesquita RCG, Meyer CFJ, Bobrowiec PED, Laurance SGW (2018) An Amazonian rainforest and its fragments as a laboratory of global change. Biol Rev 93:223-247. https://doi.org/10.1111/brv.12343

Lindborg R, Eriksson O (2004) Historical landscape connectivity affects present plant species diversity. Ecology 85:1840-1845. https://doi.org/10.1890/04-0367

Lister A (2014) Mammoths: ice age giants. Natural History Museum, London

Luoto M, Rekolainen S, Aakkula J, Pykälä J (2003) Loss of plant species richness and habitat connectivity in grasslands associated with agricultural change in Finland. Ambio 32:447-452. https://doi. org/10.1639/0044-7447(2003)032[0447:LOPSRA]2.0.CO;2

Mace GM (1994) Classifying threatened species: means and ends. Philos Trans R Soc Lond B 344:91-97

Mace GM (2014) Whose conservation? Science 345:1558-1560. https://doi.org/10.1126/science.12547 04

Mace GM, Collar NJ, Gaston KJ, Hilton-Taylor C, Akçakaya HR, Leader-Williams N, Milner-Gulland EJ, Stuart SN (2008) Quantification of extinction risk: IUCN's system for classifying threatened species. Conserv Biol 22:1424-1442. https://doi.org/10.1111/j.1523-1739.2008.01044.x

Manton M, Angelstam P (2018) Defining benchmarks for restoration of green infrastructure: a case study combining the historical range of variability of habitat and species' requirements. Sustainability 10:326. https://doi.org/10.3390/su10020326

Marris E (2011) Rambunctious garden: saving nature in a post-wild world. Bloomsbury, New York

Marris E (2014) 'New conservation' is an expansion of approaches, not an ethical orientation. Anim Conserv 17:516-517. https://doi.org/10.1111/acv.12129 
Marull J, Tello E, Fullana N, Murray I, Jover G, Font C, Coll F, Domene E, Leoni V, Decolli T (2015) Long-term bio-cultural heritage: exploring the intermediate disturbance hypothesis in agroecological landscapes (Mallorca, c. 1850-2012). Biodivers Conserv 24:3217-3251. https://doi. org/10.1007/s 10531-015-0955-Z

McClure SB (2015) The pastoral effect: Niche construction, domestic animals, and the spread of farming in Europe. Curr Anthropol 56:901-910. https://doi.org/10.1086/684102

Mehrabi Z, Ellis EC, Ramankutty N (2018) The challenge of feeding the world while conserving half the planet. Nat Sustain 1:409-412. https://doi.org/10.1038/s41893-018-0119-8

Meltzer DJ (2015) Pleistocene overkill and North American mammalian extinctions. Annu Rev Anthropol 44:33-53. https://doi.org/10.1146/annurev-anthro-102214-013854

Milberg P, Bergman K-O, Cronwall E, Eriksson ÅI, Glimskär A, Islamovic A, Jonason D, Löfqvist Z, Westerberg L (2016) Flower abundance and vegetation height as predictors for nectar-feeding insect occurrence in Swedish semi-natural grasslands. Agric Ecosyst Environ 230:47-54. https:// doi.org/10.1016/j.agee.2016.05.029

Mitchell FJG (2005) How open were European primeval forests: hypothesis testing using palaeoecological data. J Ecol 93:168-177. https://doi.org/10.1111/j.1365-2745.2004.00964.x

Myers N, Mittermeier RA, Mittermeier CG, da Fonseca GAB, Kent J (2000) Biodiversity hotspots for conservation priorities. Nature 403:853-858. https://doi.org/10.1038/35002501

Ollerton J, Erenler H, Edwards M, Crockett R (2014) Extinctions of aculeate pollinators in Britain and the role of large-scale agricultural changes. Science 346:1360-1362. https://doi.org/10.1126/scien ce. 1257259

Öster M, Cousins SAO, Eriksson O (2007) Size and heterogeneity rather than landscape context determine plant species richness in semi-natural grasslands. J Veg Sci 18:859-868. https://doi. org/10.1111/j.1654-1103.2007.tb02602.x

Öster M, Ask K, Cousins SAO, Eriksson O (2009) Dispersal and establishment limitation reduces the potential for successful restoration of semi-natural grassland communities on former arable fields. J Appl Ecol 46:1266-1274. https://doi.org/10.1111/j.1365-2664.2009.01721.x

Pereira HM, Leadley PW, Proença V, Alkemade R, Scharlemann JPW, Fernandez-Manjarrés JF, Araújo MB, Balvanera P, Biggs R, Cheung WWL, Chini L, Cooper D, Gilman EL, Guénette S, Hurtt GC, Huntington HP, Mace GM, Obersdorff T, Revenga C, Rodrigues P, Scholes RJ, Sumaila UR, Walpole M (2010) Scenarios for global diversity in the $21^{\text {st }}$ century. Science 330:1496-1501. https:// doi.org/10.1126/science. 1196624

Pérez-Sánchez AJ, Schibalski A, Schröder B, Klimek S, Dauber J (2020) Disentangling the effects of host resources, local and landscape variables on the occurrence pattern of the dusky large blue butterfly (Phengaris nausithous) in upland grasslands. J Insect Conserv 24:327-341. https://doi. org/10.1007/s10841-019-00204-3

Phalan B, Onial M, Balmford A, Green RE (2011) Reconciling food production and biodiversity conservation: land sharing and land sparing compared. Science 333:1289-1291. https://oi.org/10.1126/ science. 1208742

Phalan B, Green RE, Dicks LV, Dotta G, Feniuk C, Lamb A, Strassburg BBN, Williams DR, Zu Ermgassen KHJ, Balmford A (2016) How can higher-yield farming help spare nature? Science 351:450451. https://doi.org/10.1126/science.aad0055

Pimentel D, Stachow U, Takacs DA, Brubaker HW, Dumas AR, Meaney JJ, O’Neil JAS, Onsi DE, Corzilius DB (1992) Conserving biological diversity in agricultural/forestry systems. Bioscience 42:354-362. https://doi.org/10.2307/1311782

Pimm SL, Russell GJ, Gittleman JL, Brooks TM (1995) The future of biodiversity. Science 269:347350. https://doi.org/10.1126/science.269.5222.347

Pimm SL, Jenkins CN, Abell R, Brooks TM, Gittleman JL, Joppa LN, Raven PH, Roberts CM, Sexton JO (2014) The biodiversity of species and their rates of extinction, distribution, and protection. Science 344:1246752. https://doi.org/10.1126/science.1246752

Pimm SL, Jenkins CN, Li BV (2018) How to protect half the Earth to ensure it protects sufficient biodiversity. Sci Adv 4:eaat2616. https://doi.org/10.1126/sciadv.aat2616

Plieninger T, Höchtl F, Spek T (2006) Traditional land-use and nature conservation in European rural landscapes. Environ Sci Policy 9:317-321. https://doi.org/10.1016/j.envsci.2006.03.001

Plieninger T, Hartel T, Martín-López B, Beaufoy G, Bergmeier E, Kirby K, Montero MJ, Moreno G, Oteros-Rozas E, van Uytvanck J (2015) Wood-pastures of Europe: geographic coverage, socialecological values, conservation management, and policy implications. Biol Conserv 190:70-79. https://doi.org/10.1016/j.biocon.2015.05.014 
Poschlod P, Bonn S (1998) Changing dispersal processes in the central European landscape since the last ice age: an explanation for the actual decrease of plant species richness in different habitats. Acta Bot Neerl 47:27-44

Poschlod P, WallisDeVries MF (2002) The historical and socioeconomic perspective of calcareous grasslands-lessons from the distant and recent past. Biol Conserv 104:361-376. https://doi. org/10.1016/S0006-3207(01)00201-4

Raatikainen KJ, Barron ES (2017) Current agri-environmental policies dismiss varied perceptions and discourses on management of traditional rural biotopes. Land Use Policy 69:564-576. https://doi. org/10.1016/j.landusepol.2017.10.004

Ridding LE, Redhead JW, Pywell RF (2015) Fate of semi-natural grassland in England between 1960 and 2013: a test of national conservation policy. Global Ecol Conserv 4:516-525. https://doi. org/10.1016/j.gecco.2015.10.004

Rivals F, Lister AM (2016) Dietary flexibility and niche partitioning of large herbivores through the Pleistocene of Britain. Quat Sci Rev 146:116-133. https://doi.org/10.1016/j.quascirev.2016.06.007

Roberts N, Fyfe RM, Woodbridge J, Gaillard M-J, Davis BAS, Kaplan JO, Marquer L, Mazier F, Nielsen AB, Sugita S, Trondman A-K, Leydet M (2018) Europe's lost forests: a pollen-based synthesis for the last 11,000 years. Sci Rep 8:716. https://doi.org/10.1038/s41598-017-18646-7

Rook AJ, Dumont B, Isselstein J, Osoro K, WallisDeVries MF, Parente G, Mills J (2004) Matching type of livestock to desired biodiversity outcomes in pastures-a review. Biol Conserv 119:137-150. https://doi.org/10.1016/j.biocon.2003.11.010

Rotchés-Ribalta R, Winsa M, Roberts SPM, Öckinger E (2018) Associations between plant and pollinator communities under grassland restoration respond mainly to landscape connectivity. J Appl Ecol 55:2822-2833. https://doi.org/10.1111/1365-2664.13232

Rowley-Conwy P (2011) Westward ho! The spread of agriculture from central Europe to the Atlantic. Curr Anthropol 52:S431-S451. https://doi.org/10.1086/658368

Rydin H, Diekmann M, Hallingbäck T (1997) Biological characteristics, habitat associations, and distribution of macrofungi in Sweden. Conserv Biol 11:628-640. https://doi.org/10.104 6/j.1523-1739.1997.96437.x

Saatchi S, Agosti D, Alger K, Delabie J, Musinsky J (2001) Examining fragmentation and loss of primary forest in the southern Bahian Atlantic forest of Brazil with radar imagery. Conserv Biol 15:867-875. https://doi.org/10.1046/j.1523-1739.2001.015004867.x

Sánchez-Bayo F, Wyckhuys KAG (2019) Worldwide decline of the entomofauna: a review of its drivers. Biol Conserv 232:8-27. https://doi.org/10.1016/j.biocon.2019.01.020

Sandom CJ, Ejrnæs R, Hansen MDD, Svenning J-C (2014) High herbivore density associated with vegetation diversity in interglacial ecosystems. Proc Natl Acad Sci USA 111:4162-4167. https://doi. org/10.1073/pnas.1311014111

Sjödin NE, Bengtsson J, Ekbom B (2008) The influence of grazing intensity and landscape composition on the diversity and abundance of flower-visiting insects. J Appl Ecol 45:763-772. https://doi.org/ $10.1111 / \mathrm{j} .1365-2664.2007 .01443 . x$

SLU ArtDatabanken (2020) Rödlistade arter i Sverige 2020. SLU, Uppsala ((the 2020 Swedish Red List; In Swedish with English summary))

Smith FDM, May RM, Pellew R, Johnson TH, Walter KR (1993a) How much do we know about the current extinction rate? Trends Ecol Evol 8:375-378. https://doi.org/10.1016/0169-5347(93)90223-C

Smith FDM, May RM, Pellew R, Johnson TH, Walter KS (1993b) Estimating extinction rates. Nature 364:494-496. https://doi.org/10.1038/364494b0

Stork NE (2010) Re-assessing current extinction rates. Biodivers Conserv 19:357-371. https://doi. org/10.1007/s 10531-009-9761-9

Svenning J-C (2002) A review of natural vegetation openness in north-western Europe. Biol Conserv 104:133-148. https://doi.org/10.1016/S0006-3207(01)00162-8

Svenning J-C, Pedersen PBM, Donlan CJ, Ejrnæs R, Faurby S, Galetti M, Hansen DM, Sandel B, Sandom CJ, Terborgh JW, Vera FWM (2016) Science for a wilder Anthropocene: synthesis and future directions for trophic rewilding research. Proc Natl Acad Sci USA 113:898-906. https://doi. org/10.1073/pnas.1502556112

Svensson R, Berg A, Hamring L, Rätz C, Zhmihorski M (2017) Mowing in power-line corridors: effects on vascular plants over a 13-year period. Sven Bot Tidskr 111:16-28 (in Swedish with English summary)

Swedish Board of Agriculture (2005) Ängs- och betesmarksinventeringen 2002-2004. Rapport 2005: 1. Jordbruksverket, Jönköping. (In Swedish with English summary). https://www2.jordbruksverket .se/webdav/files/SJV/trycksaker/Pdf_rapporter/ra05_1.pdf. Accessed 23 Apr 2019 
Swedish Board of Agriculture (2019) Plan for odlingslandskapets biologiska mångfald. Rapport 2019:1 . Jordbruksverket, Jönköping. (In Swedish). https://www2.jordbruksverket.se/download/18.36d57 baa168c704154d46f04/1549611543321/ra19_1.pdf. Accessed 12 Apr 2019

Tieskens KF, Schulp CJE, Levers C, Lieskovský J, Kuemmerle T, Plieninger T, Verburg PH (2017) Characterizing European cultural landscapes: accounting for structure, management intensity and value of agricultural and forest landscapes. Land Use Policy 62:29-39. https://doi.org/10.1016/j. landusepol.2016.12.001

Tilman D, May RM, Lehman CL, Nowak MA (1994) Habitat destruction and the extinction debt. Nature 371:65-66. https://doi.org/10.1038/371065a0

Tilman D, Clark M, Williams DR, Kimmel K, Polasky S, Packer C (2017) Future threats to biodiversity and pathways to their prevention. Nature 546:73-81. https://doi.org/10.1038/nature22900

Tscharntke T, Tylianikis JM, Rand TA, Didham RK, Fahrig L, Batáry P, Bengtsson J, Clough Y, Crist TO, Dormann CF, Ewers RM, Fründ J, Holt RD, Holzschuh A, Klein AM, Kleijn D, Kremen C, Landis DA, Laurance W, Lindemayer D, Scherber C, Sodhi N, Steffen-Dewenter I, Thies C, van der Putten W, Westphal C (2012) Landscape moderation of biodiversity patterns and processeseight hypotheses. Biol Rev 87:661-685. https://doi.org/10.1111/j.1469-185X.2011.00216.x

van Klink R, van der Plas F, van Noordwijk CGE, WallisDeVries MF, Olff H (2015) Effects of large herbivores on grassland arthropod diversity. Biol Rev 90:347-366. https://doi.org/10.1111/brv.12113

van Swaay C, Warren M, Loïs G (2006) Biotope use and trends of European butterflies. J Insect Conserv 10:189-209. https://doi.org/10.1007/s10841-006-6293-4

Veen P, Jefferson R, de Smidt J, van der Straaten J (eds) (2009) Grasslands in Europe of high nature value. KNNV Publishing, Zeist

Vera FWM (2000) Grazing ecology and forest history. CABI Publishing, Wallingford

Vieilledent G, Grinand C, Rakotomalala FA, Ranaivosoa R, Rakotoarijaona J-R, Allnutt TF, Achard F (2018) Combining global tree cover loss data with historical national forest cover maps to look at six decades of deforestation and forest fragmentation in Madagascar. Biol Conserv 222:189-197. https:// doi.org/10.1016/j.biocon.2018.04.008

Waldén E, Lindborg R (2016) Long term positive effect of grassland restoration on plant diversity—success or not? PLoS ONE 11:e155836. https://doi.org/10.1371/journal.pone.0155836

Whitehouse NJ, Smith D (2010) How fragmented was British Holocene wildwood? Perspectives on the "Vera" grazing debate from the fossil beetle record. Quat Sci Rev 29:539-553. https://doi. org/10.1016/j.quascirev.2009.10.010

Willerslev E, Davison J, Moora M et al (2014) Fifty thousand years of Arctic vegetation and megafaunal diet. Nature 506:47-51. https://doi.org/10.1038/nature12921

Willett W, Rockström J, Loken B et al (2019) Food in the Anthropocene: the EAT-lancet commission on healthy diets from sustainable food systems. Lancet 393:447-492. https://doi.org/10.1016/S0140 $-6736(18) 31788-4$

Wilson EO (2016) Half-Earth: our planet's fight for life. Liveright Publishing Corporation, New York

Wilson JB, Peet RK, Dengler J, Pärtel M (2012) Plant species richness: the world records. J Veg Sci 23:796802. https://doi.org/10.1111/j.1654-1103.2012.01400.x

Wuerthner G, Crist E, Butler T (eds) (2014) Keeping the wild: against the domestication of earth. Island Press, Washington

Zobel M, Davison J, Edwards MF, Brochmann C, Coissac E, Taberlet P, Willerslev E, Moora M (2018) Ancient environmental DNA reveals shifts in dominant mutualisms during the late Quaternary. Nat Commun 9:139. https://doi.org/10.1038/s41467-017-02421-3

Publisher's Note Springer Nature remains neutral with regard to jurisdictional claims in published maps and institutional affiliations. 